\title{
Prevalence of Attention Deficit Hyperactivity Disorder and Comorbid Disruptive Behavior Disorders Among School Age Children in Trabzon
}

\author{
Neyir Gul, Ahmet Tiryaki (Assistant Professor), S. Ebru Cengel Kultur \\ (Assistant Professor), Murat Topbas \& Ismail Ak (Professor)
}

To cite this article: Neyir Gul, Ahmet Tiryaki (Assistant Professor), S. Ebru Cengel Kultur (Assistant Professor), Murat Topbas \& Ismail Ak (Professor) (2010) Prevalence of Attention Deficit Hyperactivity Disorder and Comorbid Disruptive Behavior Disorders Among School Age Children in Trabzon, Klinik Psikofarmakoloji Bülteni-Bulletin of Clinical Psychopharmacology, 20:1, 50-56, DOI: 10.1080/10177833.2010.11790634

To link to this article: https://doi.org/10.1080/10177833.2010.11790634

\section{(c) 2010 Taylor and Francis Group, LLC}

曲 Published online: 04 Nov 2016.

Submit your article to this journal

Џll Article views: 139

View related articles

Citing articles: 8 View citing articles ¿ 


\title{
Prevalence of Attention Deficit Hyperactivity Disorder and Comorbid Disruptive Behavior Disorders Among School Age Children in Trabzon
}

\author{
Neyir Gul', Ahmet Tiryaki', S. Ebru Cengel Kultur ${ }^{3}$, Murat Topbas', Ismail Ak
}

ÖZET:

Trabzon ili ilköğretim çağı cocuklarında dikkat eksikliği hiperaktivite bozukluğu ve eşlik eden yıkıcı davranış bozuklukları yaygınlığı

Amaç: Bu çalışmanın amacı Trabzon ilinde ilköğretim çağı çocuklarında Dikkat Eksikliği Hiperaktivite Bozukluğu'nun (DEHB) ve ona eşlik eden Yıkıcı Davranış Bozuklukları́nın (YDB) yaygıınlığını incelemektir.

Yöntem: Çalışmada 6-12 yaş aralığındaki ilkokul öğrencilerinde $(n=1126)$ DSM-IV tanı ölçütlerine göre DEHB ve YDB tanılarının konulması amacı ile Turgay'ın Çocuk ve Ergenlerde Davranım Bozuklukları için DSM-IV'e Dayalı Tarama Ölçeği kullanılmıştır.

Bulgular: DEHB yaygınlığı \%8.6 ( $n=97)$ ve alt tip dağılımları dikkat eksikliği \%1.6 $(n=18)$, hiperaktif/ dürtüsel tip \%6 $(n=69)$ ve kombine \%0.9 $(n=10)$ olarak sıralanmıștır. Erkek kız oranı DEHB'nin tüm alt tipleri için 3.5/1 olarak bulunmuştur. Örneklemde diğer YDB yaygınlığı \%18.6 $(n=209)^{\prime}$ dır. Karşıt Gelme-Karşı Olma Bozukluğu'nun (KG-KOB) yaygınlığı \%14.1 ( $n=159)$ ve Davranım Bozukluğu'nunki (DB) \%4.4 $(n=50)$ olarak belirlenmiștir. DEHB olan olgularda KG-KOB'nin sıklığı \%57.5 ( $n=56)$ ve DB'nin sıklığı \%20.6 ( $n=20)^{\prime}$ dır.

Sonuç: Bu çalışmanın sonuçları DEHB yaygınlığının, erkek baskınlığının ve eşlik eden YDB sıklığının kültürler arasında anlamlı bir farklılık göstermediği görüşünü desteklemektedir. Öte yandan hiperaktif/ dürtüsel alt tipin dağılımı literatürde sunulan oranlardan farklılık göstermektedir. Bu farkın Türk toplumunda çocuğa yönelik yaşa bağlı tutumlar, yaklaşım örüntüleri ve beklentilerle ilişkili kültürel farklarla şekilllenebileceği değerlendirilmiştir. Bu noktanın kültürel farklara odaklanan ileri çalışmalarla açıklanması önerilmektedir.

Anahtar sözcükler: Dikkat Eksikliği Hiperaktivite Bozukluğu, epidemiyoloji, alttipler, ektanı, yıkıcı davranım bozuklukları.

Klinik Psikofarmakoloji Bülteni 2010;20:50-56

\section{ABSTRACT:}

Prevalence of attention deficit hyperactivity disorder and comorbid disruptive behavior disorders among school age children in Trabzon

Objective: The aim of this study is to determine the prevalence of Attention Deficit Hyperactivity Disorder (ADHD) and co-morbid Disruptive Behavior Disorders (DBDs) in a sample of primary school children in Trabzon, Turkey.

Method: Primary school children aged 6-12 years $(n=1126)$ were assessed for the DSM-IV criteria of ADHD and co-morbid DBDs using Turgay's DSM-IV based ADHD and disruptive behavior disorders screening scale.

Results: The prevalence of ADHD was $8.6 \%(n=97)$ and the subtypes were predominantly inattentive $1.6 \%(n=18)$ predominantly hyperactive/impulsive $6.1 \%(n=69)$ and combined $0.9 \%(n=10)$ respectively. The male to female ratio was 3.5/1 for ADHD (all subtypes). The prevalence of other DBDs in the study sample was $18.6 \%(n=209)$. The cases were distributed as Oppositional Defiant Disorder (ODD) $14.1 \%(n=159)$ and Conduct Disorder (CD) $4.4 \%$ $(n=50)$ respectively. The frequency of ODD among ADHD cases was $57.5 \%(n=56)$ and that of CD was $20.6 \%(n=20)$. Conclusions: It was supported that ADHD did not show significant differences among cultures regarding its prevalence, male predominance and high DBD co-morbidity. On the other hand, the ADHD subtype distribution differed from the literature in favor of the predominantly hyperactive/impulsive subtype. This may be related to cultural differences in attitudes toward child and expectations and patterns related to age and situation appropriate behaviors and should be further investigated in Turkey.

Key words: Attention Deficit Hyperactivity Disorder epidemiology, subtypes, comorbidity, disruptive behavior disorders.

Bulletin of Clinical Psychopharmacology 2010;20:50-56
'Karadeniz Technical University Graduate School of Social Sciences, Counseling Psychology Master of Arts Program in Educational Sciences

${ }^{2}$ MD, Assistant Professor, Karadeniz Technical University Faculty of Medicine, Department of Psychiatry

${ }^{3} \mathrm{MD}$, Assistant Professor, Hacettepe University Faculty of Medicine, Department of Child and Adolescent Psychiatry ${ }^{4} \mathrm{MD}$, Karadeniz Technical University Faculty of Medicine, Department of Public Health ${ }^{5} \mathrm{MD}$, Professor, Karadeniz Technical University Faculty of Medicine, Department of Psychiatry KTÜ Tıp Fakültesi Farabi Hastanesi Psikiyatri AD, Trabzon, Turkey

Yazışma Adresi / Address reprint requests to: Numan Konuk, MD, Associate Professor, Istanbul University, Cerrahpasa Faculty of Medicine, Department of Psychiatry, Turkey

Elektronik posta adresi / E-mail address: nkonuk@gmail.com

Kabul tarihi / Date of acceptance: 26 Ekim 2009 / October 26, 2009

Bağıntı beyanı:

N.G., A.T., S.E.C.K., M.T., I.A.: yok.

Declaration of interest:

N.G., A.T., S.E.C.K., M.T., I.A.: none.

\section{INTRODUCTION}

Attention Deficit Hyperactivity Disorder (ADHD) is a common, impairing and persistent disorder characterized by inattention, impulsivity, and overactivity (1). Children diagnosed with ADHD continue to show ADHD symptoms at different levels throughout adolescence and adulthood in $40-80 \%$ of cases, leading to numerous problems including poor academic performance, learning disorders, low occupational status, poor social adjustment, increased risk of substance abuse, increased risk for accidents, conduct disorder, and anxiety and mood disorders (2-5). In spite of high morbidity, a large majority of children with ADHD, predominantly in the inattentive subtype, remain undiagnosed or do not receive appropriate specialist services (6-8). Epidemiological 
studies are important in determining the exact nature of the disorder and the service utilization to treat cases with ADHD and comorbid conditions. Despite the large volume of studies dedicated to ADHD, the prevalence of ADHD and its subtypes differs among cultures (9-11). In school aged children its prevalence has been reported in the range of 0.2 to $27 \%$ (12-16). The subtypes of ADHD also differ among studies from different geographical locations (17).

Although ADHD has been accepted as a cross cultural diagnosis (18), the validity of an ADHD diagnosis and cultural differences related to the symptomatology has been questioned due to these huge differences among different cultures (19). The variability in the prevalence of ADHD in the literature has been found to reflect a completely diverse methodology among studies. Methodological characteristics significantly associated with this variance can be listed as the inclusion of impairment for the diagnosis, diagnostic criteria, the source of information, age ranged assessed, and also the geographical location of the studies $(18,20)$. Among them, cultural factors have been thought to be modulators of the clinical manifestation of disruptive behavior disorders $(21,22)$. Thus, cross-cultural studies of ADHD and comorbid disruptive behavior disorders (DBDs) which apply a similar research methodology in the different cultures have become more important, in order to make study findings comparable (23). There is still a need to define a common diagnostic method in epidemiological studies of ADHD $(24,25,16,26)$. In this study we have used both the teachers and parents as sources of information and we adhered to the DSM-IV criteria (1) excluding impairment to determine probable ADHD cases.

In Turkey, there is only one study which reported the prevalence for ADHD and Oppositional Defiant Disorder (ODD) (11). A recent study observed that there is a variation by geographic region in the rates of attention problems, as measured by youth self reports, teacher report forms, and child behavior checklists in Turkey (27). The multi-ethnic and multi-cultural characteristics of Turkey make it a necessity to determine the prevalence of ADHD, subtypes and co-morbid DBDs in the different parts of Turkey. It is accepted that the planning and utilization of diagnostic and treatment services for children with ADHD and co-morbid DBDs can be achieved with a clearer understanding of its prevalence, comorbidities and cultural aspects. In this study we aimed to determine the prevalence of probable ADHD and comorbid disruptive disorders in school age children in Trabzon and to examine the subtype distribution of ADHD.

\section{METHODS}

\section{Subjects}

Subjects were chosen using a multistage clustered and stratified sampling from six of all schools (total 77 schools) in Trabzon, a province on the east part of the Black Sea coast of Turkey. Schools were divided into three different groups, according to socioeconomic status (SES), as low, moderate, and high SES. The sample size was calculated based on a $30 \%$ prevalence $(\mathrm{P})$ of ADHD, with a 3\% uncertainty level (d), using the formula $\mathrm{n}=\mathrm{Z}^{2}{ }_{1-\alpha / 2} \mathrm{P}(1-\mathrm{P}) / \mathrm{d}^{2} \quad(\mathrm{Z}=1.960$, with $95 \% \mathrm{CI})$. The sample size calculation was made using the formula for the sample size estimation of a single proportion (28). The pooled prevalence (5.29\%) of ADHD was used as the P value (20). We estimated that this would necessitate a sample of at least 896 students. However, this was increased by a further $30 \%$ because of possible reductions in the number of subjects available, due to absence from school or home, or a failure to give informed consent for participation in the study. Of these, 1126 parents and teachers of students participated in the study. Approvals were granted by the Trabzon Directorate of National Education and the head of the individual schools. Informed consent was taken from the parents after the aims and objectives of the study had been thoroughly explained to them.

Pupils aged $6-12$ years $(n=1126)$ formed the study group. All students in the study were given Turgay's DSM-IV based ADHD and disruptive behavior disorders screening scale consisting of DSM-IV criteria for DBDs that was to be completed by their parents and teachers ( 29 , 30). This scale scans 18 symptoms of ADHD, eight symptoms of ODD and 15 symptoms of conduct disorder and each symptom was rated for severity on a four point likert scale according to its frequency $(0=$ never, $1=$ occasionally, 2 = often, and 3 = very often). When the symptom count is needed, symptoms that occur "often" 
or "very often" are considered as present, and those that occur "never" or "occasionally" are considered absent.

During the process of diagnosis, the DSM-IV criteria were applied concerning the required number of symptoms. Accordingly, it was considered as a probable case of ODD and Conduct Disorder (CD) if a child attained a score of 2 or 3 on at least three items of $\mathrm{CD}$ and at least four items of ODD by the parent or teacher, respectively. A score of 2 or 3 on at least six of the hyperactivity-impulsivity items was the criterion for the hyperactive-impulsive subtype. Similarly, a score of 2 or 3 on at least six of the inattention items were the criteria for the inattentive subtype. The combined subtype was classified by combining at least six of both the hyperactivity-impulsivity and inattention items.

The DSM-IV requires impairment in at least two settings (home, school, or job) to meet the criteria for the disorder. We could not include the impairment criterion of the DSM-IV due to difficulties in defining clinical impairment with the scales available in Turkey. So we do not use the term "ADHD caseness", instead we use "probable ADHD". Although being symptomatic cannot be taken as being impaired; we gathered information from multiple informants to evaluate children better in different settings. We used the "combined" algorithms to optimally generate the diagnoses by using information from both parent and teacher. As a general rule Boolean logic (i.e., "ands" or "ors") has been applied in these "combined" algorithms (31). Each has its advantages and disadvantages. The "or" rule prevents under-reporting by one informant. On the other hand, it may also be criticized as being over-inclusive. When it is applied in epidemiological studies, it seems possible to interpret the results using the "or rule" as the upper bound prevalence of the disorder. The Diagnostic Interview Schedule for Children (DISC) Version IV uses the "or rule" with a combination of different sources of information and it is commonly used in epidemiologic studies as a respondentbased highly structured interview for lay interviewers (31). ADHD has a unity in itself different from other psychopathologies. An important challenge in the diagnosis of ADHD is that agreement between parents and teachers regarding the categorical diagnoses of ADHD and its subtypes is found to be relatively poor $(32,33,11)$. However obtaining information from at least two settings is necessary in order to make a decision. As a result we used the "and rule" in combining parent and teacher reports in the diagnosis of ADHD, and the "or rule" for the ODD and CD diagnoses. This is because it is expected to obtain non-overlapping information from multiple informants in case of DBDs and it is indicated that informants should not be taken as adequate substitutes for other informants of certain behaviors in a given setting (32).

\section{Statistical analysis}

The SPSS for Windows Version 11 (SPSS Inc., Chicago, IL) was used for the statistical analysis. The results were calculated as frequencies (\%), means and standard deviations. Pearson's Chi Square was used in calculating differences between groups. All tests were 2tailed, and the level of significance was set at $\mathrm{P}<0.05$.

\section{RESULTS}

In total, 1500 students were invited to participate the study and data coming from 1126 (75.1\%) of them who properly completed all the procedures was analyzed. The gender distribution of the students participating in the study was $54.3 \%(n=611)$ male and $45.7 \% \quad(n=515)$ female. The age range of the whole group was between 6 and 12 years, and the mean age was $9.0 \pm 1.3$ years for males and $9.0 \pm 1.2$ years for females. The majority of the students were at 10 years of age, only 6 students $(0.5 \%)$ were 12 years old.

The prevalence of ADHD was $8.6 \%(\mathrm{n}=97)$ among 1126 school-age children. The subtypes were distributed as predominantly inattentive $1.6 \%(\mathrm{n}=18)$, predominantly hyperactive/ impulsive $6.1 \%(\mathrm{n}=69)$ and combined $0.9 \%$ $(\mathrm{n}=10)$.

The male to female ratio was 3.5/1 for ADHD. The total number of males was $78(12.8 \%)$ and the number of females was $19(3.7 \%)$ and the gender difference was not statistically significant in the predominantly inattentive subtype of ADHD (2.0\% male, $1.2 \%$ female; $\mathrm{p}=0.409)$. Of the 69 predominantly hyperactive/impulsive subtype of ADHD, 57 (9.3\%) were male and 12 (2.3\%) were female $(p<0.001)$. When the gender distribution was assessed for the combined subtype of ADHD it was found that the number of males $(n=9,1.5 \%)$ were higher than females $(\mathrm{n}=1,0.2 \%)$ and the differing rates were statistically 
Table 1: The distribution of ODD diagnosis within ADHD subtypes.

\begin{tabular}{lccccc} 
& $\begin{array}{c}\text { ODD positive } \\
(\mathbf{n}=\mathbf{5 6})\end{array}$ & $\begin{array}{c}\text { ODD negative } \\
(\mathbf{n = 4 1 )}\end{array}$ & Statistics \\
\hline Predominatly hyperactive/impulsive $(\mathrm{n}=69)$ & $\mathbf{n}$ & $\mathbf{\%}$ & $\mathbf{n}$ & \% & $>0.05$ \\
Predominatly inattentive $(\mathrm{n}=18)$ & 39 & 56.5 & 30 & 43.5 & 50.0 \\
Combined $(\mathrm{n}=10)$ & 9 & 50.0 & 9 & 20.0
\end{tabular}

Table 2: The distribution of CD diagnosis within ADHD subtypes.

\begin{tabular}{lccccc} 
& \multicolumn{2}{c}{$\begin{array}{c}\text { CD } \\
(\mathbf{n = 2 0})\end{array}$} & $\begin{array}{c}\text { CD negative } \\
(\mathbf{n}=\mathbf{7 7})\end{array}$ & Statistics \\
\hline Predominatly hyperactive/impulsive $(\mathrm{n}=69)$ & $\mathbf{n}$ & $\%$ & $\mathbf{n}$ & $\%$ & $>0.05$ \\
Predominatly inattentive $(\mathrm{n}=18)$ & 14 & 20.3 & 55 & 79.7 & 83.3 \\
Combined $(\mathrm{n}=10)$ & 3 & 16.7 & 15 & 70.0
\end{tabular}

significant $(\mathrm{p}=0.025)$. In the male to female ratio, it was observed that the combined subtype of ADHD had the highest gender difference in favor of boys. The male/female ratio was $7.5 / 1,4.0 / 1,1.7 / 1$ for the combined, hyperactive impulsive and inattentive subtypes respectively.

The prevalence of other DBDs in the study sample was $18.6 \%(n=209)$. The cases were distributed as ODD $14.1 \%(n=159)$ and CD 4.4\% $(n=50)$. The frequency of ODD among ADHD cases was $57.5 \%(n=56)$ and that of CD was $20.6 \%(n=20)$. The distributions of ODD and CD were not differed within all subtypes of ADHD (Table 1 and 2 , respectively).

\section{DISCUSSION}

The aim of this study was to determine the prevalence of ADHD and co-morbid DBDs and to examine the subtype distribution of ADHD in Trabzon, Turkey. The results showed an ADHD prevalence rate of $8.6 \%$ among children aged 6 to 12 year-olds. When we reviewed studies which used a method similar to ours, that had the features of using DSM-IV based scales, obtaining information from parent and teacher, and including a primary school age group (any age between 6 and 12 years old or grade 1-5) as the research population, we found nine studies. Among them seven studies used the "and rule" and two studies used the "or rule" in combining parent and teacher reports. Studies which used the "and rule" reported ADHD prevalence from North Carolina USA, Brazil - South America, Crete - Greece, the Island of Majorca - Spain, Australia, Italy as follow; $16.0 \%$, $13.0 \%, 6.5 \%, 4.6 \%, 2.4 \%$, and $1.4 \%(24,34,25,35,36$, 37). The ADHD prevalence as reported in the studies that used the "or rule" from Nigeria - West Africa and Maracaibo - Venezuela are as follows: $8.7 \%$ and $7.2 \%$ $(38,39)$. Although our result is higher than the worldwide pooled prevalence $(5.29 \%)$ of ADHD (20), it is consistent with the rates of several of the studies above. Wolraich et al. (40) imposed the requirement of the impairment criterion, which has been found to significantly alter the prevalence of ADHD (all types) from 16.1\% to 6.8\% when included in the study. Our result of a higher prevalence of ADHD could be explained by our exclusion of the impairment criterion which in a meta analytic study has also been found to be associated with higher prevalence rates of ADHD (20). When we looked the study from Turkey, our result is comparable to their result $8.1 \%(11)$, where the main differences in methodology are the age distribution of the research population, the combination of parent and teacher reports and the location of the studied population. Erşan et al. studied a higher age group from the eastern part of the Central Anatolian region of Turkey (11). When age increases, it has been shown that the prevalence of ADHD decreases; the prevalence ranged in school aged children from 2.4 to 
$16.1 \%$ and in the adolescents it ranged from 2.2 to $9.9 \%$ $(41,20,16)$. When we consider the age and "or rule" factors together, they may balance each other and result in a similar prevalance rate for Turkey.

The subtypes of ADHD also differed among studies in relation to the methodological differences (17). The frequency of ADHD subtypes found in this study displayed a different distribution when compared to the studies which provide the methodological similarity mentioned before. Studies that used the "and rule" from North Carolina - USA, Brazil - South America, Crete Greece, Island of Majorca - Spain, Australia, Italy reported the most common subtypes as follows; combined subtype, combined subtype, no report of subtype distribution, combined subtype, predominantly inattentive subtype, no report of subtype distribution (24,34,25,35,36,37, respectively). The ADHD prevalence as reported in the studies that used the "or rule" from Nigeria - West Africa and Maracaibo - Venezuela are as follows; predominantly inattentive subtype and combined subtype $(38,39$, respectively). While the combined and inattentive subtypes were found as the prevalent subtypes, hyperactive impulsive subtype was found to be the least frequent in the most of epidemiological studies (17). Different from ADHD literature, the hyperactive/impulsivity subtype of ADHD was found to be the most common subtype in our study similarly to the study of Erşan et al. from Turkey (11). It is obvious that there are many variables affecting the subtype distribution; however differences in expectations and patterns related to age and situation appropriate behaviors could be an explanation for those high rates of the hyperactive impulsive subtype of ADHD in Turkey.

The need for the identification of consistent neuropsychological and genetic correlates for the subtypes of ADHD continues in the literature. In the literature it was suggested that the subtypes may differ from each other in many aspects $(42,43)$. For example, no significant cognitive deficits were observed in the hyperactive/impulsivity subtype of ADHD and they have been found to have more social and behavioral problems $(44,45,46)$. Woo and Rey (46) proposed that the hyperactive/ impulsivity subtype might be more closely related to the oppositional-conduct disorder construct than to the inattentive-hyperactive one. To interpret the results from Turkey regarding the subtype distribution, further population based studies should be designed.

When we looked for other DBDs, the prevalence of ODD and CD and comorbidity rates with ADHD were consistent with the literature, and the ODD and CD comorbidity was significantly associated with the diagnosis of ADHD (all types). In literature, it is known that ODD was observed co-morbid to ADHD in the range of 40 to $70 \%$ and $\mathrm{CD}$ was determined in a range of 30 to $50 \%(47,5)$.

Although data from the clinical population indicates a 6:1 to $9: 1$ ratio of males to females, the ratios drop to $3: 1$ to $4: 1$ in epidemiology studies $(3,26)$. A consistent finding in the ADHD literature is the greater number of males than females (3.1/1), which has been replicated in our study also, with the male/female ratio of $6 / 1,4.2 / 1$, $2 / 1$ for combined, hyperactive impulsive and inattentive subtypes respectively. Consistent with the ADHD literature, the predominantly inattentive subtype of ADHD did not show male predominance. However, all other subtypes were more prevalent in boys than girls (41).

Our results should be evaluated carefully due to some limitations; these include the absence of impairment criterion of the DSM-IV, not using multiple diagnostic tools and criteria to exclude children with severe developmental disabilities, or attending special classes. Another limitation is not evaluating probable cases using structured diagnostic procedures. Our evaluation was only based on high levels of symptoms with duration of least six months. These limitations also lead to insufficiency of multivariate analysis to further evaluate clinical variations. Our results cannot be interpreted as a clinical diagnosis, and also cannot be generalized to the whole Turkey because it was obtained from only the Black Sea region of the country, and Turkey's being a multiethnic and multi-cultured country. On the other hand, there is a handful of studies researching epidemiology of attention problems (27) and the distribution of symptoms and prevalence of ADHD and ODD (11) in Turkey. Also, despite a high number of studies regarding ADHD and its subtype distribution and comorbidities, epidemiologic studies among different ethnicities and cultures are not sufficient enough and epidemiologic studies are crucial in the understanding the mentioned clinical entities. So our study could be motivating for further studies.

In conclusion, our results showed concordance with 
the literature and support the idea that ADHD does not show significant differences among cultures regarding its prevalence, male predominance, and high DBD comorbidity. In contrast to the literature, we observed a high prevalence of the ADHD predominantly hyperactive/ impulsive subtype in Turkey. This could be related to cultural factors related to parental discipline and the parent child relationship, and should be investigated further to improve the understanding, etiology, and the natural history of the ADHD and its subtypes.

\section{References:}

1. American Psychiatric Association. Diagnostic and statistical manual of mental disorders, 4th edn., American Psychiatric Association, Washington D.C. : 1994

2. Gittelman R, Mannuzza S, Shenker R, Bonagura N. Hyperactive boys almost grown up, I: psychiatric status. Arch Gen Psychiatry $1985 ; 42: 937-947$

3. Barkley RA, Fischer M, Edelbrock CS, Smallish L. The adolescent outcome of hyperactive children diagnosed by research criteria, I: an 8-year prospective follow-up study. J Am Acad Child Adolesc Psychiatry 1990; 29:546-557

4. Barkley RA, Fischer M, Smallish L, Fletcher K. The persistence of attention-deficit/hyperactivity disorder into young adulthood as a function of reporting source and definition of disorder. J Abnorm Psychol 2002; 111: 279-289

5. Biederman J. Attention-deficit/hyperactivity disorder: a selective overview. Biol Psychiatry 2005; 57:1215-1220

6. Sayal K, Taylor E, Beecham J, Byrne P. Pathways to care in children at risk of Attention Deficit/Hyperactivity Disorder. Br J Psychiatry $2002 ; 181: 43-48$

7. Sayal K, Goodman R, Ford T. Barriers to the identification of children with Attention Deficit/Hyperactivity Disorder. J Child Psychol Psychiatry 2006; 47:744-750

8. Neuman RJ, Sitdhiraksa N, Reich W, Ji TH, Joyner CA, Sun LW, Todd RD. Estimation of prevalence of DSM-IV and latent classdefined ADHD subtypes in a population-based sample of child and adolescent twins. Twin Res Hum Genet 2005; 8:392-401

9. Schaffer D, Fisher P, Lucas CP, Dulcan MK, Schwab-Stone ME. NIMH Diagnostic Interview Schedule for Children version IV (NIMH DISCIV): description differences from the previous versions, and reliability of some common diagnosis. J Am Acad Child Adolesc Psychiatry 2000; 39:28-38

10. Rohde LA. ADHD in Brazil: The DSM-IV criteria in a culturally different population. J Am Acad Child Adolesc Psychiatry 2002; 41:1131-1133

11. Erşan EE, Doğan O, Doğan S, Sümer H. The distribution of symptoms of attentiondeficit/ hyperactivity disorder and oppositional defiant disorder in school age children in Turkey. Eur Child Adolesc Psychiatry 2004; 13:354-361

12. Cantwell DP. Attention deficit disorder: a review of the past 10 years. J Am Acad Child Adolesc Psychiatry 1996; 35:978-987

13. Brown RT, Freeman WS, Perrin JM, Stein MT, Amler RW, Feldman HM, Pierce K, Wolraich ML. Prevalence and assessment of attention-deficit/hyperactivity disorder in primary care settings. Pediatrics 2001; 107:43

14. Leung, AK, Lemay JF. Attention deficit hyperactivity disorder: an update. Adv Ther 2003; 20:305-318

15. Mannuzza S, Klein RG, Moulton JL. Persistence of attention deficit/ hyperactivity disorder into adulthood: what have we learned from the prospective follow-up studies? J Atten Disord 2003; 7:93-100

16. Polanczyk G, Jensen P. Epidemiologic Considerations in Attention Deficit Hyperactivity Disorder: A Review and Update. Child Adolesc Psychiatr Clin N Am 2008; 17:245-260

17. Rowland AS, Skipper B, Rabiner DL, Umbach DM, Stallone L, Campbell RA, Hough RL, Naftel AJ, Sandler DP. The shifting subtypes of ADHD: classification depends on how symptom reports are combined. J Abnorm Child Psychol 2008; 36:731-743

18. Faraone SV, Sergeant J, Gillberg C, Biederman J. The worldwide prevalence of ADHD: is it an American condition? World Psychiatry $2003 ; 2: 104-113$

19. Timimi S, Taylor E. ADHD is best understood as a cultural construct. Br J Psychiatry 2004; 184:8-9

20. Polanczyk G, de Lima MS, Horta BL, Biederman J, Rohde LA. The worldwide prevalence of ADHD: a systematic review and metaregression analysis. Am J Psychiatry 2007; 164:942-948

21. Reid R. Assessment of ADHD with culturally different groups: the use of behavioral rating scales. Sch Psychol Rev 1995; 24:537-560

22. Livingston R. Cultural issues in diagnosis and treatment of ADHD. J Am Acad Child Adolesc Psychiatry 1999; 38:1591-1594

23. Rohde LA, Szobot C, Polanczyk G, Schmitz M, Martins S, Tramontina S. Attention-Deficit/Hyperactivity Disorder in a Diverse Culture: Do Research and Clinical Findings Support the Notion of a Cultural Construct for the Disorder? Biol Psychiatry 2005; 57:14361441

24. Rowland AS, Umbach DM, Catoe KE, Stallone L, Long S, Rabiner D, Naftel AJ, Panke D, Faulk R, Sandler DP. Studying the epidemiology of attention-deficit hyperactivity disorder: screening method and pilot results. Can J Psychiatry 2001; 46:931-940

25. Skounti M, Philalithis A, Mpitzaraki K, Vamvoukas M, Galanakis E. Attention-deficit/hyperactivity disorder in schoolchildren in Crete. Acta Paediatr 2006; 95:658-663

26. McClellan J, Bresnahan MA, Echeverria D, Knox SS, Susser E. Approaches to psychiatric assessment in epidemiological studies of children. J Epidemiol Community Health 2009; 63: i4-i14

27. Erol N, Simsek Z, Oner O, Munir K. Epidemiology of attention problems among Turkish children and adolescents: a national study. J Atten Disord 2008; 11:538-545 
28. Lemeshow S, Hosmer DW, Klar J, Lwanga SK. Adequacy of Sample Size in Health Studies. The World Health Organization and John Wiley and Sons, New York, NY: 1990

29. Turgay A. Turgay's DSM-IV based ADHD and disruptive behaviour disorders screening scale, Integrative Therapy Institute Publication, Toronto-Ontario, Canada: 1997

30. Ercan ES, Amado S, Somer O. Dikkat Eksikligi hiperaktivite Bozuklugu ve Yikici Davranis Bozukluklari icin bir test bataryasi gelistirme calismasi. Cocuk ve Genclik Ruh Sagligi Dergisi (Journal of Child and Adolescent Mental Health) 2001; 8:132-144

31. Shaffer D, Fisher PW, Lucas CP. Respondent based interviews. In: Shaffer D, Lucas CP, Richters JE (eds) Diagnostic assessment in child and adolescent psychopathology. Guilford Press, 1999: 3-34

32. Jensen PS, Watanabe HK, Richters JE, Roper M, Hibbs ED, Salzberg AD, Liu S. Scales, diagnoses, and child psychopathology: II. Comparing the CBCL and the DISC against external validators. J Abnorm Child Psychol 1996; 24:151-168

33. Mitsis EM, McKay KE, Schulz KP, Newcorn JH, Halperin JM Parent-teacher concordance for DSM-IV attentiondeficit/hyperactivity disorder in a clinic-referred sample. J Am Acad Child Adolesc Psychiatry 2000; 39:308-313

34. Fontana RS, Vasconcelos MM, Werner J Jr, Góes FV, Liberal EF. ADHD prevalence in four Brazilian public schools. Arq Neuropsiquiatr 2007; 65:134-137

35. Cardo E, Servera M, Llobera J. Estimation of the prevalence of attention deficit hyperactivity disorder among the standard population on the island of Majorca. Rev Neurol 2007; 44:10-14

36. Gomez R, Harvey J, Quick C, Scharer I, Harris G. DSM-IV AD/HD: confirmatory factor models, prevalence, and gender and age differences based on parent and teacher ratings of Australian primary school children. J Child Psychol Psychiatry 1999; 40:265274

37. Zuddas A, Marzocchi GM, Oosterlaan J, Cavolina P, Ancilletta B, Sergeant J. Factor structure and cultural factors of disruptive behaviour disorders symptoms in Italian children. Eur Psychiatry 2006; 21:410-418
38. Adewuya AO, Famuyiwa OO. Attention deficit hyperactivity disorder among Nigerian primary school children prevalence and co-morbid conditions. Eur Child Adolesc Psychiatry 2007; 16:10-15

39. Montiel-Nava C, Peña JA, López M, Salas M, Zurga JR, MontielBarbero I, Pirela D, Cardozo JJ. Estimations of the prevalence of attention deficit hyperactivity disorder in Marabino children. Rev Neurol 2002; 35:1019-1024

40. Wolraich ML, Hannah JN, Baumgaertel A, Feurer ID. Examination of DSM-IV criteria for attention deficit/hyperactivity disorder in a county-wide sample. J Dev Behav Pediatr 1998; 19:162-168

41. Skounti M, Philalithis A, Galanakis E. Variations in prevalence of attention deficit hyperactivity disorder worldwide. Eur J Pediatr 2007; 166:117-123

42. Rohde LA. Is there a need to reformulate attention deficit hyperactivity disorder criteria in future nosologic classifications? Child Adolesc Psychiatr Clin N Am 2008; 17:405-420

43. Cakaloz B, Pekcanlar Akay A., Böber E. Dikkat eksikliği hiperaktivite bozukluğu ve eşlik eden karşıt olma karşı gelme bozukluğu olan prepubertal erkek çocuklarda plazma kortizol düzeylerinin değerlendirilmesi. Klinik Psikofarmakoloji Bülteni 2005; 15: 158-164

44. Chhabildas N, Pennington BF, Willcutt EG. A comparison of the neuropsychological profiles of the DSM-IV subtypes of ADHD. J Abnorm Child Psychol 2001; 29:529-540

45. Nigg JT, Blaskey LG, Huang-Pollock CL, Rappley MD Neuropsychological executive functions and DSM-IV ADHD subtypes. J Am Acad Child Adolesc Psychiatry 2002; 41:59-66

46. Woo BSC, Rey JM. The validity of the DSM-IV subtypes of attention-deficit/hyperactivity disorder. Aust N Z J Psychiatry 2005; $39: 344-353$

47. Keller MB, Lavori PW, Beardslee WR, Wunder J, Schwartz CE, Roth J, Biederman J. The disruptive behavioral disorder in children and adolescents: comorbidity and clinical course. J Am Acad Child Adolesc Psychiatry 1992; 31:204-209 